\title{
Strategic Financial Planning in Malaysia's National School: New Strategies for Education Transformation
}

\author{
Norfariza Mohd Radzi \\ Department of Educational Management, Planning \& Policy \\ Faculty of Education, University of Malaya \\ Kuala Lumpur, Malaysia \\ norfariza@um.edu.my
}

\begin{abstract}
The public national schools of the third millennium have to be given an opportunity to become more autonomous along the lines of the primary financial resources of government fund. The schools should have ownership of the school and its own resources through the commitment and capacity of the school staff and community. This conceptual paper discuss the important concepts in the strategic financial planning of Malaysia's national schools and the recommendation of new strategies to face the new dimensions of $21^{\text {st }}$ century education. The international trend of decentralized school system should create opportunity for national schools to have greater autonomy in strategically plan for the school financial resources. The concept of strategic financial planning encompassed the important process of school financial analysis, budgeting management, financial accounting and reporting and finding stable school financial resources for achieving the education goals effectively. To cope with future education transformation, national schools have a clear on school vision and mission establishment, defining financial purposes, school finance organizational structure, role of financial planner and an excellent budget management procedure.
\end{abstract}

Keywords—strategic; finance; planning; school; autonomy

\section{INTRODUCTION}

Government of Malaysia is constantly committed towards providing an optimum education funds for the education and development of human capital in Malaysia. Education is perceived as among the main tools for country development and nations advancement that required for a proper plan and preparation particularly on the provision of sufficient financial resources. In the year 2011, the country's education expenditure was amounted to $3.8 \%$ of Gross Domestic Product (GDP), which was more than the average percentage of $3.4 \%$, by the Organization for Economic Cooperation and Development (OECD). [1] This effort was absolutely intended to enable schools to concentrate on delivering the best teaching and learning programs, which then further increase the students academic level and overall school performance.

In embracing the $21^{\text {st }}$ century education change and challenge, Malaysia has established the Malaysia Education Development Plan or Pelan Pembangunan Pendidikan Malaysia (PPPM) 2013-2025. This plan includes the macro and micro plan on various important aspects including maximizing the current performance through purposeful expenditure and resource productivity. The whole plan is monitored through three phases or waves of operation with the final aim to maximize the students' outcome and the overall quality of education. In relation to the plan, school leaders in Malaysia national schools are increasingly granted a guided autonomy through the establishment of Sekolah Berprestasi Tinggi or High Performing Schools and Sekolah Kluster Kecemerlangan or Cluster schools. The guided autonomy covers important aspects generally practiced under the school-based management concept, which includes autonomy and accountability in managing the school financial resources. It drives responsibility of the school leaders to have their own strategic financial planning to ensure for effective and efficient flow of money.

A major component of the school-based management reform has been the delegation of the financial management to the school authority. [2] Therefore, it places greater autonomy on the part of the school leaders, managers and the relevant stakeholders to use the money effectively. They will become accountable for the duty to supply the money to the most proper channel with further obligation to report on it. With regard to this situation, accountability indicates the conditions of being obligated or subject to give an account over the school financial matters. [3] Halim Shafie, Zulkifli Idris, Saraswathy \& Shahid-din Mohd Khatib [4] have described financial accountability as one of three related categories of accountability other than management accountability and program accountability. Financial accountability claimed for the obligation on regulation, rules and instruction related with the financial matters and also the integrity associated in the accounts and financial reports.

Overall, this conceptual paper discusses the important element of strategic financial planning by public national schools in Malaysia to embrace the education transformation that requires for an effective and efficient flow of financial resources. Generally, schools have to establish a good school vision and mission, clear on the school financial purpose, properly equipped with a comprehensive school financial organizational structure, clearly defined role of financial planner and a systematic budget management procedures. However, all the school financial stakeholder need to have good understanding on the major concepts exist in the school financial planning such as budgeting management, school financial resources 
and financial accounting and reporting particularly relevant to the Malaysia school context.

\section{CONCEPTS OF SCHOOL FINANCIAL PLANNING}

\section{A. Budgeting management}

Budgeting is defined as a financial plan performed in a specific predetermined financial year that involves at least four elements that are planning, receiving funds, spending funds and evaluating the results. [5] It contains a proposed plan for implementing the organization's objectives, policies and programs, which is expressed in monetary terms. Xavier [6] described budgeting as a process of planning for revenues and spending them in a meaningful way to meet organizational needs. The meaningful way is through setting the organization's objectives and further developing and executing a set of programs or activities to achieve them.

The budgeting process is the vital part of the financial management of an organization. It acts as a mechanism in transforming the school financial resources into the supporting devices in the process of teaching and learning which includes the school facilities, teaching materials and even the payment for all staff who are going to run the school activities. Therefore, the crucial task in decentralization of school finance lay upon the autonomy of schools in handling their own budget to be able to better arrange the school programs towards achieving the final aim of educational outcomes. Furthermore, it should act as a planning instrument or a decision model of the school management for the next financial year and beyond.

Budget exists to serve many functions. It can be used for the school's term planning, coordinating activities and communicating the plans to the relevant school members. Furthermore, it can be used for motivating personnel, bringing authority for expenditures and for implementing the plan in that particular year. [7] Specifically, the objectives of having the budgeting management as detailed by Malaysia's National Audit Department are: i) to prepare for the estimated revenue and expenses of an organization in one formal document, ii) to direct the aim of the organization's plan in order to achieve its objectives, iii) to ensure a systematic allocation of money in satisfying organizational needs, iv) to ensure control over the allocation in order to avoid any over expenses, v) to make evaluation on the allocated expenses that have been spent and the overall organizational aims, and finally vi) to ensure accountability in handling the organization's money when the budget report is prepared for the authorities and relevant stakeholders.

The budgeting method adopted by Malaysia's public sector has passed through four different kinds of methods since the early independence of Malaysia in 1957. The earliest method adopted was the traditional line item budgeting, which estimates expenditures by a budget object name without addressing the purpose. After several suggested improvements that planned to redress some misgivings in the line item budgeting, the government of Malaysia has switched to apply the Programme and
Performance Budgeting System (PPBS) starting in 1969 till 1989. The PPBS emphasized the creating of programme structures to enable the matching of resources and output and also the performance evaluation based on the objective setting for each program component. Then, in 1990, the Modified Budgeting System (MBS) came into practice in all Malaysian government departments given certain shortcomings of the PPBS and the shift in the public sector management paradigm from the Progressive Public Administration to New Public Management. MBS has been practiced by the Malaysian government with the objectives of improving the rational allocation of resources and achieving better and accountable program management.

In recent decade, Government in Malaysia has started the application of the Outcome-Based Budgeting (OBB) method to all government ministries and departments. It has been test-bedded in selected ministries in 2012 and further applied across the public sector from 2013 onwards. Primarily, the purpose of Outcome-Based Budgeting (OBB) is to increase the quality of government operation through the concept of value for money in all of the budget expenditure management. This is in parallel with government's aspiration and vision to make Malaysia a high-income nation by 2020 through efficient, effective and economic operations. OBB includes three main components that are Result-Based Budgeting (RBB), Results-Based Performance Evaluation and Results-Based Management Information System. All these components will ensure that the resources that have been allocated are able to achieve specific goals and objectives and measured results. [8]

The implementation of OBB involved four main processes presented as a strategic cycle. The four main processes are outcome-based planning, budget preparation, budget monitoring and evaluation and finally the outcome reporting. Outcome-based planning is the process of determining specific plans at the ministry level in order to achieve the target within the period of five years. Then, the budget will be coordinated for the level of Activity and level of Program including the Development Expenditure (DE) and Operational Expenditure (OE). This process is then followed by the monitoring and evaluation actions by the ministries for all Programs/Activities using online application of MyResults to measure the level of achievement. This cycle is ended with the issuance of outcome reporting by all ministries to the Ministry of Finance such as the Quarterly and Yearly Performance Report, Program Monitoring Report, Report on Program Formative and Summative Evaluation and a few others.

The application of OBB has been adopted by public national schools in a slightly different ways. As a result of decentralization reform around the world, schools have created the school-based budgeting concept, which was also known as site-based budgeting. Based on the lump-sum of money granted by the higher authorities, the head teachers or school managers will further manage the money according to their school's need by examining their programs and set their budgets to meet the particular school 
objectives. School financial committees will be established which are then granted with decision making authority and held accountable for the results. They will work collaboratively in planning for the school finances by utilizing a specific budgeting method, which requires them to justify their individual budget requests.

Generally, budgeting management involves a few steps recognized as a budget cycle, which include the phase of planning, development, implementation, monitoring, control and evaluation. In the planning stage, the team responsible for doing the budget will specify the budget goals and objectives, which actually link back to the school's aim and mission. Then, the budget development is the phase where estimation will be made and the budget proposal will be handed in by the relevant parties involved in the budget preparation. Only after agreement has been reached will the budget be implemented and further monitored to ensure that every financial transaction falls within the proposed budget. Any discrepancies will be identified and the necessary corrective actions will be taken in the control phase to respond to any changes for unexpected revenue or expenses. Lastly, the evaluation stage is important for measuring the budget performance and assisting schools in strategic planning goal achievement.

\section{B. School financial resources}

Obtaining resources is an important element in the school financial management as an indicator of the school capability to provide needs for the school operations. It is not limited only to the financial assets but includes other forms of school resources and many way of financing the school expenses. Public national schools obtained their main financial source from the central, state or local government with the main sources derived from the tax revenue system. It has become the responsibility for government to distribute it equitably among public institutions in accordance to certain budgets and allocation as a form of beneficial service or welfare to society.

In most national public school systems, financial resources are derived from two main sources, namely government funding and non-government funding. [9] [10] [11] The government fund is distributed in the form of grant per capita or based on certain calculations over number of students enrolled in schools. The funds are also differentiated between the allocation for subjects or curriculum delivery and allocations for other school operations such as extra curriculum activities, staff salaries, school maintenance and development and any others. Then, the non-government funding involved the money received from people such as additional tuition fees, donations and income from school bank deposits or small business activities.

In a broader context of education funding, Saavedra [12] has recognized three main sources of education finance that are public finance, private sources of finance and international sources. Public finance represents the largest proportion of school funds particularly for public schools followed by the private sources, which include mostly fund received from households, communities, society organizations and the private sector. International sources are basically in the form of loans from external parties such as international, bilateral and multilateral agencies especially for the less developed countries in support of education development.

The concept of cost sharing in education has evolved around the 1980s and 1990s as a supporting mechanism for education expenses in all levels of education. [13] The source of education financing has widened to prevent a single reliance on the government grant and assistance. Bray has classified the cost sharing alternatives into three main categories to show some distinctions. The first form is the fee or levy charged to the consumer of education services. Another form is contribution forwarded by factories, businesses or enterprises to schools or could be in the form of school-business partnership. It could result in mutual benefits by both parties such as the claim for tax relief by the businesses themselves or coordination for the future needs of the workforce. [14] Then, the third form of cost sharing is the community financing through the contribution of communities for schools resources and assets. It was believed to be an important aspect of cost sharing in order to promote feelings of ownership and public interest in school operations and activities.

Overall, the concept of school-based financial management still poses the public sector or government as the principal provider of education. Nevertheless, financial autonomy granted at school level provides a certain level of flexibility for school leaders to vary the school financial resources within certain boundaries of government rules and regulations. The concept of cost sharing and community participation through various forms of contributions could strengthen the school financial position thus enabling schools to have greater benefit as compared to conventional public schools financial management. This could create a more transparent school financial system and avoid the risks of single monitoring of school funds by the principal only.

\section{Financial accounting and reporting}

According to Garner [15], school accounting is the process that records, classifies and summarizes the school financial transactions and provides a history of the school business activities. Financial reports will be prepared at the end of each fiscal year, which discloses the results of a school's business operation and the status of its resources. Ray, Candoli, and Hack [16] elaborate three main ideas behind the definition of school accounting. Primarily, school accounting deals with activities and events that affect both operational inputs such as money, material and the school's programs. Then, accounting process involves the acts of recording, classifying, analyzing and interpreting data. Finally, accounting activities involve the process of recording the school financial conditions as of a given date and the evaluation of the status and results of financial operation in terms of the established objectives. 
In support of the budgeting management, the accounting system exists as a tool to structure, organize and operationalize the school financial planning and budgeting. In addition, the financial reporting conveys some information to the school stakeholders on every type of school fund established which could help them in the future decision making through evaluation of the fund's financial performance. Thus, a complete and satisfactory management of the accounting system is important in order to achieve effective school financial management. [17] It will assists the organization's management in doing future budget and financial allocations, facilitating a smooth and effective auditing process and finally help explain the accountability of the school authorities who actually act as public representatives.

Generally, the school accounting procedure adopted in many countries around the world is in accordance to the Generally Accepted Accounted Principles (GAAP), which is the universally practiced standard that indicates how to report economic events. Furthermore, a Governmental Accounting Standard Board or GASB is established to provide guidance for all states and local governmental bodies in terms of the accounting procedures that should be undertaken and how the financial funds are being operated. In the case of Malaysian schools, financial management and accounting procedures are bounded by the Education Act 1996, Financial Act 1957, Account \& Audit Rules 2002, Treasury Directive and financial circulation letters that are disseminated primarily by the Ministry of Education or Accountant General Office. Currently, the main reference for school book keeping and accounting method is the guideline published by the Financial Division, Ministry of Education, namely the Procedure of Financial Management and Accounting for School Monetary Group.

Among other characteristics which differentiate the financial operation of the school-based management (SBM) and the previous centralized public school management is the various sources of money that fill in the school funds which came from the stakeholders or other kind of efforts. Briggs and Wohlstetter [18] even highlighted that one of the eight elements associated with the characteristics of a successful SBM strategy is the ability of the school to cultivate resources from outside the school. This will either come from the school involvement in professional networks or through the entrepreneurial activities in the local business community. In the context of public schools in Malaysia, there are four main groups of financial funds generally established by the school manager or principal in the school financial operation. The four groups are the group of government money, the group that come from public or being called Sumber Wang Awam (SUWA), the hostel money group and the small allocation warrant group. [19]

The frequent practice by the principals or the school governing body (SGB) in school financial management is to set up the finance committee and sub committees who have the specialized knowledge and skills to carry out the financial operational and technical matters. However, all the decisions made by the finance committee should always be under the knowledge of the principals or the school governing body (SGB) and being ratified by them due to the real accountability held by the principals and the SGB. [20] In the context of Malaysian public schools, the ultimate accountability is still vested in the hands of the principals or head teachers. Nevertheless, the principals will be responsible for setting up the school financial committee, which consists of a group of staff directly involved in school financial operations. The school financial committee will be led by the principal, and includes vice principal, administrative assistant, senior assistant, head of department, head of division and senior teachers.

In short, school financial resources have to be financially managed through proper and efficient financial accounting and reporting. Schools with financial autonomy are particularly accountable with more groups of school stakeholders for the reporting of school financial positions in a more transparent way. The acceptance and payment of financial transactions required good accounting principles, ethics and proper conduct to ensure that schools are able to obtain the greatest benefit through efficient money management. This will realize the basic purpose of financial decentralization reform occurs in government sectors and educational institutions.

\section{ELEMENTS OF STRATEGIC FINANCIAL PLANNING}

Strategic financial planning is the process of determining how an institution manages itself financially for achieving its goals, visions and mission. It involves the analysis and arrangement of future plan in monetary terms for future guidelines and references. In the context of school or education institution, strategic financial planning informed the financial priorities of the school spending together with planned strategic income and resources for three to five years. Therefore, there are several important elements that should be considered by the school leaders, managers or relevant stakeholders for establishing an excellent and successful school strategic financial plan that will assists schools in achieving its overall performance.

\section{A. School vision and mission establishment}

School vision and mission should correspond with stakeholders' desires and receive conformity by all school members. This condition will enable the school vision and mission to be collectively executed and receive full participation by all. One important element in school strategic planning is the need for school vision and mission to be established based on considerations of the school financial position. Even though the school vision and mission for public schools are dominantly inspired by the higher authority's goals or aims, it should consider the ability of the school to finance all the strategies for achieving the school mission. In Malaysia, the High Performing schools and Cluster schools are the group of schools that have achieved various goals as have been structured from their financial plan. Since these two kinds of 
schools received more allocation of money and wider alternative sources of funding, they would come out with their own financial plans that reflected their financial capability. They are also known for having a highly competitive vision and mission, which could increase the school performance at international level. Thus, the inference that could be made is that the school vision and mission must go in parallel with the school financial position.

\section{B. Defining financial purposes}

Primarily, the school financial allocation should be used to buy teaching aids for the school teaching and learning activities. In addition, the school should consider the needs for having the co curriculum activities for students or support programs for the academic and non-academic staff through various activities and arrangements. Nevertheless, it is important for schools to set high priorities and utilize the money for implementing high impact programs with low costs. The current practices revealed that every government program should be evaluated based on its outcomes and the value for money that it contributes at the end of the programs.

Another financial aim under the school-based financial management concept is to channel the money to creating conducive school surroundings and providing school facilities. The financial decentralization reform was intended to reduce the hustle of bureaucracy and facilitate school to fulfill both its basic and additional needs in educations. School leaders should also allocate financial resources for school maintenance and the provision of capital for improving the school academic quality and performance. Other than that is the school plan to channel its money to perform activities to reach for school Key Performance Index (KPI). The KPI achievement reflects the ability of school to allocate its money in the most effective way and reduce the issue of wastage and misuse of public money. In a nutshell, the pool of school fund should be allocated for producing successful students with multicapabilities and also the school capital that supports the whole process of providing excellent quality of education to the society.

\section{School finance organizational structure}

In order to set up a good school financial plan, it is important for school to establish a school finance organizational structure that can carry their responsibility with knowledge, skills and experience. In the context of Malaysia national school, the structure is lead by the Principal/Head Teacher with the support of the School Financial Management and Account Committee. As recommended by the Ministry of Education, this committee should consist of Principal or Head Teacher, all of his or her Assistants, Head of Department, Subject Senior Teachers, Chief Administrative Assistant, Financial Administrative Assistant and appointed school internal auditor. In need of the strategic financial planning, it is highly recommended for school to set up the school Asset Disposal Committee, school Asset Management and Inventory Committee,
School Development Committee and School Price Quotation Committee.

Another important process is the need for schools to appoint suitable persons among teachers to become Quality Controller for the inspection of the procurement process. It indicates the ethics of preserving the value of integrity among public workers besides high level of internal control system implemented at school level. It is also important for school to form its Key Performance Index Committee to manage the financial allocation for achieving the school Key Performance Index (KPI) especially for cluster schools or the high performing schools (SBT). Other than that, schools have to appoint a specific Financial Committee member in every school project/program that involves money consumption. It is also include the appointment of Treasurer in PTA organizational structure that particularly manages the flow of money derived from parents' donations or contributions.

\section{Role of financial planner}

Other than establishing a good structure of school financial team, it is vital for the member of the school finance organization to be clear on their specific role and responsibilities. The ultimate aim of the strategic financial plan is to ensure that school is able to use the financial resources effectively and efficiently for achieving the most prioritized instructional tasks for the benefit of students and all school members. Therefore, the school financial planner has to understand the need for the team to consider the teachers' view and opinion and the role of the Head of department to lead the decision making process. Furthermore, the role of committee in the strategic planning process should be based on their specific duties in view of their related skills and knowledge of certain job requirement.

In addition, everyone should agree on the role of principal or head teacher as the ultimate decision maker for the school budget. Teachers are given opportunities to bring their opinion to the financial committee to be analyzed and discussed before the final decision by the principal or head teacher. Another main consent for most of national schools in Malaysia is the role of Parent Teacher Association (PTA) in the school strategic financial planning. By regulation, it is clear that the PTA is empowered with authority to plan and handle the fund collected by the PTA only which is mostly for the benefits and needs of their children. Therefore, any financial plan forwarded by the school finance team should consider any plan brought by the PTA to ensure smooth flow of resources and to avoid any lost and redundancy due to miscommunication or mishandling cases.

\section{E. Budget management procedures}

The budget is prepared at the end of the year before by using a standardized format usually referred to the previous year's budget. The financial planning considers the component of input, process and outcome in implementing every school program/project before allocating the optimal amount of allocation. Then, the budget is announced at the early period of the school financial year and acts as a 
guidance to avoid any wastage and misuse of funds. In the context of school-based financial management, there should be certain level of flexibility in the financial planning policy in accordance to school needs and priorities as agreed by the school management team. This is in parallel with the study of Brown. [21]

Among important attribute of the budget management procedures is the application of strategic financial analysis as suggested in a local study by Che Ku Alam. [22] Schools have to analyze their strengths, weaknesses, opportunities and threats (SWOT analysis) of school finance. This is to ensure that school has analyzed its environment and highlighted the most priority needs for school expenditure. Tactical planning is made at the department level for the yearly financial allocation before being endorsed by the higher school management team. This reflected the application of the "bottom-up" (down to top) concept in planning the school funds associated with the concept of financial decentralization reform at school level.

\section{CONCLUSION}

As a conclusion, good strategic financial plan requires commitment by all school members to be clear on their final goals and objectives of education. It then followed by the cooperation by them to set the schools' priorities to allocate the financial resources in the most optimum way for the benefit of students and all stakeholders. Specifically, it is important for schools to understand the real concept of budgeting management, the process of school financial accounting and reporting and also the potential school income and profit that could assist schools in sustaining their financial condition. Then, there are several main elements that should be implemented in the school strategic financial process. The school members particularly the financial team should be (i) clear on the school vision and mission establishment, (ii) understand and define the school financial purposes based on priorities, (iii) setting up a wellstructured school finance committee, (iv) be clear on the role of financial planner and finally (v) implementing an excellent budget management procedures.

In sequence with the aim to realize the Malaysia Education Development Plan, strategic financial planning should become the necessary agenda for every school granted with autonomy. The principal or head teacher together with the financial team are the main player for allocating the school fund in the optimum way besides being more accountable and responsible for the duties. The school accountability on financial matters is an established responsibility in the hands of the principal or school governing body. They have to provide information on the school financial performance and be transparent to both the internal and the external parties. This is absolutely aimed at improving the quality of the school financial management and the ultime vision of the best education performance of all students.

\section{REFERENCES}

[1] Kementerian Pelajaran Malaysia. Malaysia Education Development Plan. Putrajaya: Ministry of Education Malaysia; 2013.

[2] Newcombe G, McCormick J, Sharpe F. Financial decision making: Teacher involvement and the need for trust. International Journal of Educational Management. 1997; 11(3): 94-101.

[3] Anthony HN. The edge of chaos: School administrators and accountability. Journal of Educational Administration. 2004; 42(1): 55-77. DOI: $10.1108 / 09578230410517477$

[4] Halim Shafie, Zulkifli Idris, Saraswathy R, Shahid-din Mohd Khatib. $\mathrm{Ke}$ arah memantapkan keutuhan sistem pengurusan kewangan. Buletin Kewangan. 1999; 1: 7-18.

[5] Burrup PE, Vern Brimley J, Garfield RR. Financing education in a climate of change. 6th ed. Boston, MA: Allyn and Bacon; 1996.

[6] Xavier JA. Understanding MBS (The Modified Budgeting System). Kuala Lumpur: Institut Tadbiran Awam Negara Malaysia; 2002.

[7] Knight BAA. Managing school finance. Oxford: Heinemann Educational Books; 1988.

[8] KPMG. Making the transition, outcome-based budgeting: A six nation study. Kuala Lumpur: K. I. Co-operative; 2011.

[9] Ibrahim Tamby Chek, Rosli Samat. Perakaunan dalam organisasi pendidikan. Kuala Lumpur: Pustaka Salam; 2006.

[10] Omardin Ashaari. Pengurusan sekolah: Suatu panduan lengkap. Kuala Lumpur: Utusan Publications \& Distributors; 1996

[11] Shahril@Charil Marzuki. Mengurus kewangan sekolah. Kuala Lumpur: PTS Professional; 2006

[12] Saavedra J. Education financing in developing countries: Level and sources of funds. Washington, DC: World Bank Institute; 2002.

[13] Bray M. The costs and financing of education: Trends and policy implications. In: Bray, editor. Education in developing Asia. Manila: Asian Development Bank \& Comparative Education Research Centre, The University of Hong Kong; 2002.

[14] Bray M. Financing education in developing Asia: Themes, tensions and policies. International Journal of Educational Research. 1998; 29: $627-642$.

[15] Garner CW. Education finance for school leaders: Strategic planning and administration. Eaglewood Cliffs, NJ: Pearson Education; 2004

[16] Ray JR, Candoli IC, Hack WG. School business administration: A planning approach. Boston, MA: Pearson Education; 2005.

[17] Xavier JA. Pengurusan kewangan: Teras mutu perkhidmatan awam. Buletin Kewangan. 2001; 4: 36-42.

[18] Briggs KL, Wohlstetter P. Key elements of a successful school-based management strategy. School Effectiveness and School Improvement. 2003; 14(3): 351-372. DOI: 10.1076/sesi.14.3.351.15840

[19] Kementerian Pelajaran Malaysia. Tatacara pengurusan kewangan dan perakaunan Kumpulan Wang Sekolah. 4th ed. Putrajaya: Bahagian Kewangan, Kementerian Pelajaran Malaysia; 2005

[20] Mestry R. Financial accountability: The Principal or the School Governing Body? South African Journal of Education. 2004; 24(2): 126-132.

[21] Brown DJ. Decentralization and School-Based Management. London, UK: The Falmer Press; 1990.

[22] Che Ku Alam. Pengurusan Berasaskan Sekolah (School-Based Management, SBM): Tinjauan Amalan Pengurusan Berasaskan Sekolah, Satu Pengalaman Pembelajaran di New Zealand. 2008. Retrieved from http://www.iab.edu.my/KertasKerjaSN15/CHE_KU_ALAM.pdf 